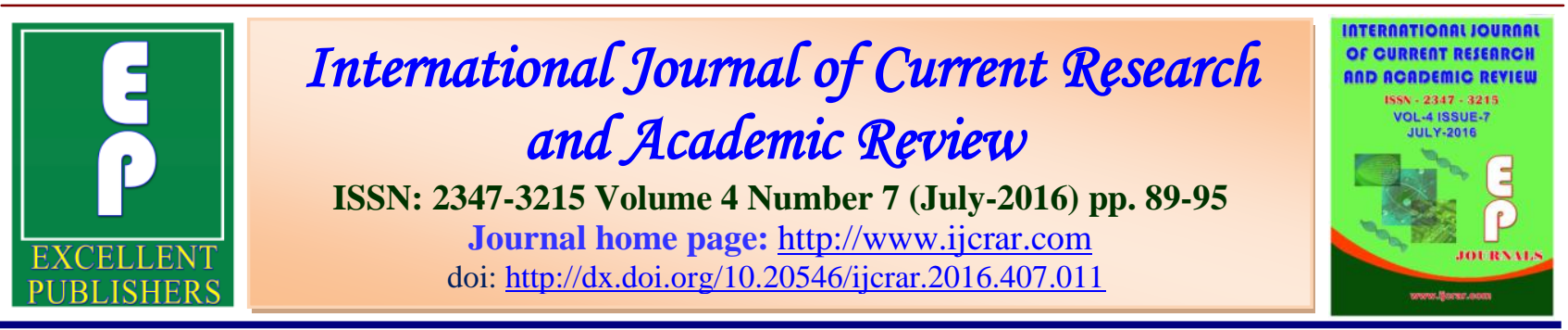

\title{
HPLC Analysis of the Total Extract and Gossypitrin Isolated from the Petals of Talipariti elatum (S.w) Fryxell (Malvaceae)
}

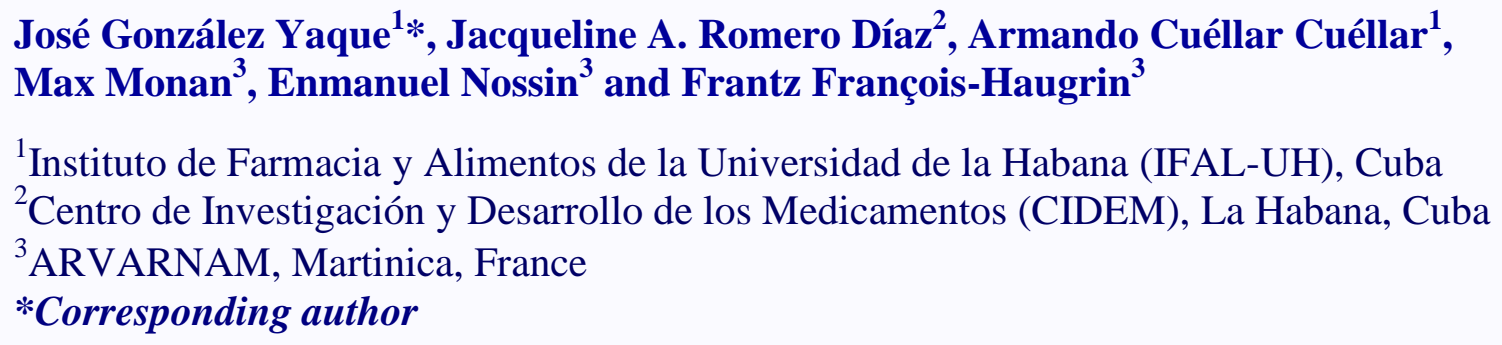

KEYWORDS

Talipariti elatum, antasthmatic, petals,

HPLC, chemical composition
A B S T R A C T

Talipariti elatum (S.w) Fryxell (Malvaceae) is a tropical Caribbean tree with a reported wide range of healing properties such as appetitive, emollient, sudorific, antasthmatic and excellent expectorant combined with the flowers of Hibiscus rosa-sinensis. In the present study, an extract from the petals of $T$. elatum collected in Cuba was analyzed to determine the chemical composition using an HPLC equipment with RP-18 flash chromatographic column, $\mathrm{MeOH}(\mathrm{A})$ and $\mathrm{H}_{2} \mathrm{O}$ (B) as eluents and gossypitrin as standard. These results provide scientific support for the empirical use of T. elatum extracts as an antasthmatic medicine.

\section{Introduction}

Talipariti elatum (S.w) Fryxell (Malvaceae) is a tree with a wide distribution in Cuba and Jamaica that grows in any type of soil, particularly in swampy ones, with a reported wide range of healing properties such as appetitive, emollient, sudorific, antasthmatic and excellent expectorant. It can get about $25 \mathrm{~m}$ of height. Its leaves are heart shaped at the basis and peciolated, with yellow flowers that change to red (Acosta and Rodríguez, 2006). In Cuba, this specie is known as Majagua, Majagua común and Majagua macho. In Jamaica it is known as Majó, Blue Mahoe, Cuba Bark and Mountain Mahoe. The mixture is used in traditional medicine as expectorant and antasthmatic (Roig, 1974).
There is an ever-increasing interest in the biological effects of the bioflavonoids, members of the large group of plant polyphenols. Because of the aromatic character of these compounds, they have been analyzed by several chromatographic methods. In the case of high-performance liquid chromatography, they are readily detected by their ultraviolet absorbance or electrochemical properties (Valls y col., 2009).

More evidence that the bioflavonoids undergo extensive metabolism during uptake from the gut and distribution around the body and in specific tissues is accumulating. 
In addition, free radicals products at sites of inflammatory processes react with bioflavonoids and their metabolites, generating important new compounds of as yet unknown properties. For these reasons, careful examination of the chemical nature of bioflavonoids and their products in biological systems is absolutely required (Lambert y Elias, 2010; Ablajan, 2011).

Combination of mass spectrometry with the various chromatographic methods has proved to be highly successful in this regard (Prasain et al., 2004). A number of analytical techniques have been used to evaluate the metabolism and bioavailability of flavonoids in vitro and in vivo (Pinheiro $y$ Justino, 2012). These methods include gas chromatography (GC), reverse-phase highpressure liquid chromatography (HPLC), and capillary electrophoresis (CE) in combination with UV absorbance, fluorescence, electrochemical detection, and mass spectrometry (MS) (Vukics y Guttman, 2010). The aim of the present study was to evaluate the amount of chemical components of an extract elaborated from the petals of the flowers of Talipariti elatum.

\section{Material and Methods}

\section{Plant material}

Plant material (petals of the flowers) was collected in January 2013 in the gardens of the Faculty of Medical Sciences "Salvador Allende" at Havana City, and identified at the herbarium of National Botany Garden of Havana, where the voucher specimen no. HAJB 82587 has been deposited.

\section{Chemicals}

All the chemicals and reagents were of analytical grade. $\mathrm{MeOH}, \mathrm{EtOH}, \mathrm{CHCl}_{3}$ and HPLC grade methanol were purchased from
Merck (Darmstadt, Germany). Reversed phase silica gel for flash chromatography, RP-18 chromatography column, and TLC silica gel with fluorescent indicator $254 \mathrm{~nm}$ on aluminium cards (layer thickness 0,2 $\mathrm{mm})(10 \times 20 \mathrm{~cm})$ DC-KARTEN SI F and silica gel 60 for chromatographic column 0,063-0,200 mm (70-230 mesh ASTM) were purchased from Merck (Darmstadt, Germany). All materials were used without further purification.

\section{Extract preparation}

The petals were separated from the rest of the components of the flower and dried in an oven with controlled temperature, at $30{ }^{0} \mathrm{C}$, during 4 days. The extracts were prepared with ethanol $95 \%$, during ten days, utilizing the maceration process. For to the purification, $1 \mathrm{~g}$ of solid was dissolved in 25 $\mathrm{mL}$ of diethyl ether and the volume was completed to $100 \mathrm{~mL}$ with ethanol. The sample was refrigerated until an abundant solid appear and it was recuperated to filtration. This process was done twice, to obtain only a yellowish-green solid monitoring by TLC on silica gel with fluorescent indicator $254 \mathrm{~nm}$ on aluminium cards (layer thickness $0,2 \mathrm{~mm})(10 \times 20 \mathrm{~cm})$ using n-butanol: acetic acid: water (4:1:5) as eluent.

\section{Isolation and HPLC determination of gossypitrin}

Experiments were carried out on a KNAUER spectrometer (Germany) equipped with an UV detector at $280 \mathrm{~nm}$ of length wave. A portion $(1 \mathrm{~mL})$ of this extract was dissolved in $50 \mathrm{~mL}$ of $\mathrm{MeOH}$ and separated on a reversed phase flash chromatography column (C-18, $60 \AA$, $5 \mu \mathrm{m}$, $250 \times 4 \mathrm{~mm}$, Eurospher), using as eluent $\mathrm{A}$ $\mathrm{MeOH}$ and eluent $\mathrm{B} \mathrm{H}_{2} \mathrm{O}$. A gradient of 15$85 \% \mathrm{~B}$ during $30 \mathrm{~min}$ at $1 \mathrm{~mL} / \mathrm{min}$ was 
followed by holding the gradient, then increasing to $50 \%$ A during $10 \mathrm{~min}$, holding $10 \mathrm{~min}$, reversing to $0 \% \mathrm{~B}$ during $5 \mathrm{~min}$, and reequilibrating for $5 \mathrm{~min}$. The determination of gossypitrin (G: compound 1) was also carried out from the solid residue dissolved in $50 \mathrm{~mL}$ of $\mathrm{MeOH}$, using the above described procedure.

\section{$T L C$}

TLC analysis of the extract and the solid yield, including gossypitrin, were performed on normal silica gel plates with fluorescent indicator $254 \mathrm{~nm}$ on aluminium cards (layer thickness $0.2 \mathrm{~mm})(10 \times 20 \mathrm{~cm})$ using as eluent (n-butanol: acetic acid: water (4:1:5); developing agent was $\mathrm{H}_{2} \mathrm{SO}_{4} / \mathrm{CeSO}_{4}$ reagent and heat. TLCP (thin layer chromatography plate) were activated under $100 \sim 105{ }^{0} \mathrm{C}$ for $30 \mathrm{~min}$ and were examined under ultraviolet $(254 \mathrm{~nm})$ and ordinary light.

\section{Semi-preparative HPLC}

Compound 1 was isolated for further analytical and pharmacological studies adopting the already established method for the separation of phenolics and ellagic acid derivatives in $T$. elatum (Cuellar \& González, 2010). Briefly, an HPLC-system consisting of two Knauer HPLC WellChrom K1001 pumps (Berlin, Germany), a Bischoff UV-VIS detector Lambda 1000 (Leonberg, Germany), and a dynamic mixing chamber was employed. The purified ethanolic extract (20 mg per injection) was loaded onto a Polaris Amide C18, $250 \mathrm{~mm} \times 10.0$ $\mathrm{mm}, 5 \mu \mathrm{m}$ column (Varian) and eluted with $0.05 \%$ (v/v) aqueous TFA (A) and acetone (B) at room temperature using a two-step gradient (24\% B to $44 \% \mathrm{~B}$ in $80 \mathrm{~min}$ and $44 \% \mathrm{~B}$ to $64 \% \mathrm{~B}$ in 30 min, $3 \mathrm{~mL} / \mathrm{min})$. All collected fractions were lyophilized. A yellow residue $(7.8 \mathrm{~g})$ was obtained after concentration under reduced pressure $\left(40{ }^{\circ} \mathrm{C}\right)$ and a portion $(2 \mathrm{~g})$ was purified by semi-preparative High Pressure Liquid Chromatography, HPLC in order to obtain around $0.8 \mathrm{~g}$ of compound 1 (purity: $96 \%$ by HPLC) and its structure was confirmed as $\mathbf{G}$ by UV and MS (Yaque et al., 2016).

\section{UV spectrum}

The UV spectrometric experiments were carried out on a JASCO ultraviolet-visible spectrometer (Japan). The scan range was 200 to $500 \mathrm{~nm}$, absorbance 0 to 2.5 , and the analyzed samples were diluted in methanol, into quartz cuvettes, comparing the obtained spectrum with the original spectrum of gossypitrin (Cuéllar \& González, 2010). The cuvettes thickness was $d=1 \mathrm{~cm}$.

\section{Results and Discussion}

\section{TLC check}

Chromatoplate presented three obvious yellow single spots, from each application, examined under ordinary light, $\mathrm{UV}_{254}$ and colorimetric detection with concentrated sulphuric acid (Fig.1), probably due to the presence of flavonoids.

\section{Identification of main flavonoid by HPLC}

The chromatographic analysis of total extracts from the petals of the flowers of $T$. elatum by HPLC allowed the identification of 48 different chemical constituents (Fig.2), including gossypitrin, the flavonoid glucoside present in the petals of the flowers of Talipariti elatum and in the solid residue.

The chromatographic analysis of $50 \mathrm{~mL}$ of total extract after elution in $50 \mathrm{~mL}$ of $\mathrm{MeOH}$ (Fig. 3) showed, at least, 29 different peaks 
with a remarkable reduction in the number of chemical constituents.

The chromatographic analysis of solid residue (Fig. 4), showed the presence of at least 15 different chemical components, a quantity lesser than the previous result, indicating an effective isolation method.

After purification by semi-preparative HPLC column, chromatographic profile showed that compound $\mathrm{G}$ reduces its retention time, but still remain the presence of several chemical constituents in the sample (Fig. 5). The unequivocal identification of these constituents required isolation by semi-preparative HPLC and MS and NMR experiments.

\section{Scan of the ultraviolet spectrum}

There were three absorption peaks at 278 $\mathrm{nm}, 332 \mathrm{~nm}$ and $382 \mathrm{~nm}$. There may be the presence of flavonoids in $95 \%$ ethanol extracts (Fig. 6).

For the first time the results showed that the extracts and solid residue of $T$. elatum exhibited a high content of metabolites after HPLC analysis of the extracts on reversed phase flash chromatography column RP-18. The $\mathrm{MeOH} / \mathrm{H}_{2} \mathrm{O}$ and $\mathrm{MeOH}$ fractions revealed complex mixtures of chemical constituents as indicated by TLC and UV analysis.

TLC analysis, under previously describe conditions, showed three yellow spots typically of flavonoid compounds, that varying in size and shape, being the biggest and largest the No. 3, follows by No. 2 and for last No. 1. All spots change colorations from yellow to greenyellowish under UV lamp at $254 \mathrm{~nm}$ and to brown with $\mathrm{H} 2 \mathrm{SO} 4$ and heat (Fig. 2). The Rf calculated values were 0,808 (1);
0,807 (2) and 0,780 (3), respectivally. These results suggesting that the isolated powders content at least only one kind of chemical compound. The presence of phenolic hydroxyl groups was observed through positive reaction with ferric chloride and aluminium chloride (Lu et al., 2007).

HPLC of solid residue indicated the presence of 15 chemical components, and gossypitrin showed a retention time of 37.9 minutes (Fig.2), 37.6 minutes (Fig. 3) and 36.4 minutes (Fig.4), respectively. This result was corroborated when the corresponding peak of gossypitrin $\left(\mathrm{R}_{\mathrm{t}}: 31.2\right.$ min) was collected after carry out on a KNAUER chromatographer with a semipreparative column (Fig.5) and analysed on a JASCO UV spectrometer. The UV spectrum (Fig.6) showed that the flavonoid has three characteristics bands at 278, 332 and $382 \mathrm{~nm}$, and one inflection at $257 \mathrm{~nm}$ (Márquez et al., 1999).

There is a big difference among these results and the results of the research on the same extraction utilizing a GC-MS technique because of the amount of chemical components. It was only of 16 for the crude extract of the petals using toluene and ethanol as eluents (González, 2007). It could be possible, due to the high sensitivity of HPLC analysis method compared with GC (Pinheiro \& Justino, 2012), or the possibility because in the presence of more or less metabolites due to the difference in time of collection of the flowers of the plant (hour, week day, etc.). Maybe the difference in the growing area or growing conditions of Talipariti elatum plantation (geographic zone, type of soil, humidity, nutrients, etc.), provoque differences in the dynamic accumulation of metabolites into the flowers. 
Fig.1 TLC of the products isolated from the ethanolic extracts of T. elatum.

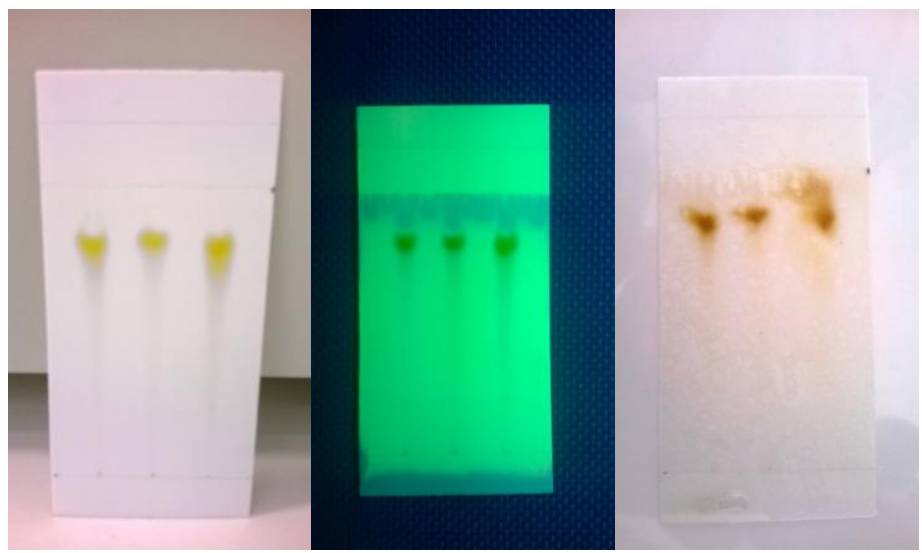

Fig.2 Chromatogram of the chemical constituents in the total extract from the petals of the flowers of T. elatum.

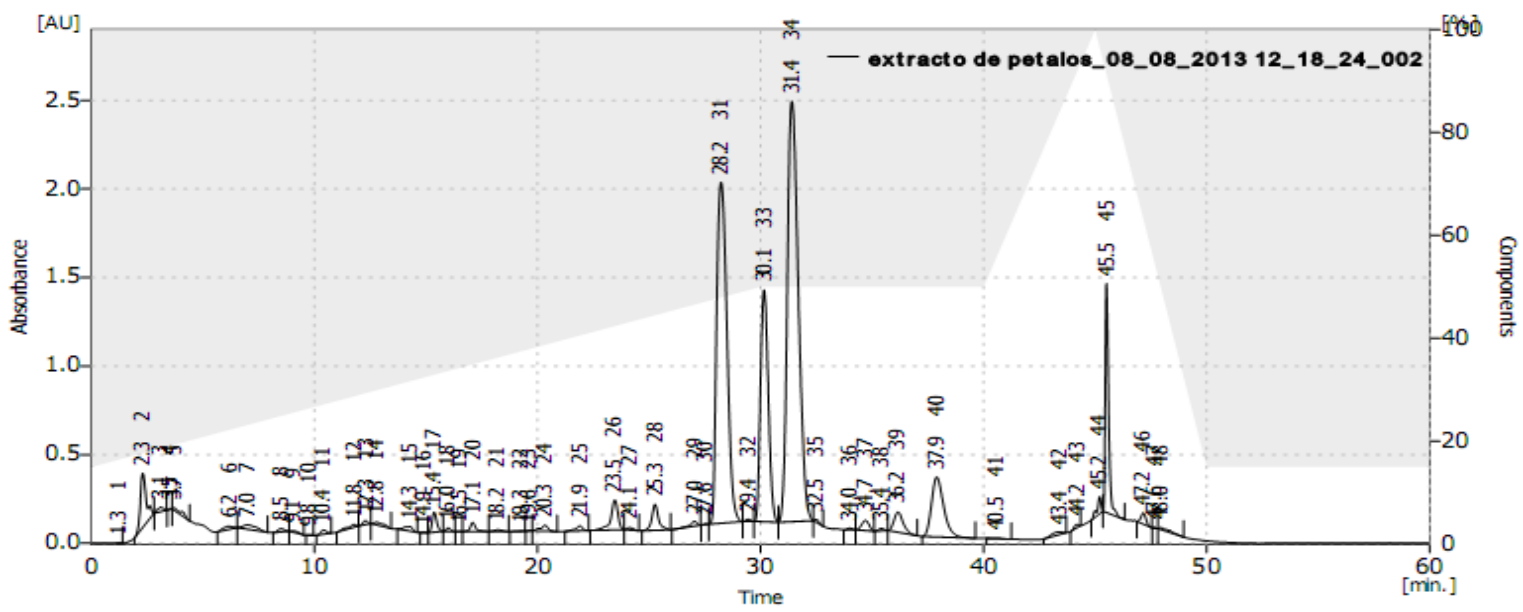

Fig.3 Chromatogram of the chemical constituents in the total extract from the petals of the flowers of $T$. elatum after elution on a reversed phase flash chromatographic column.

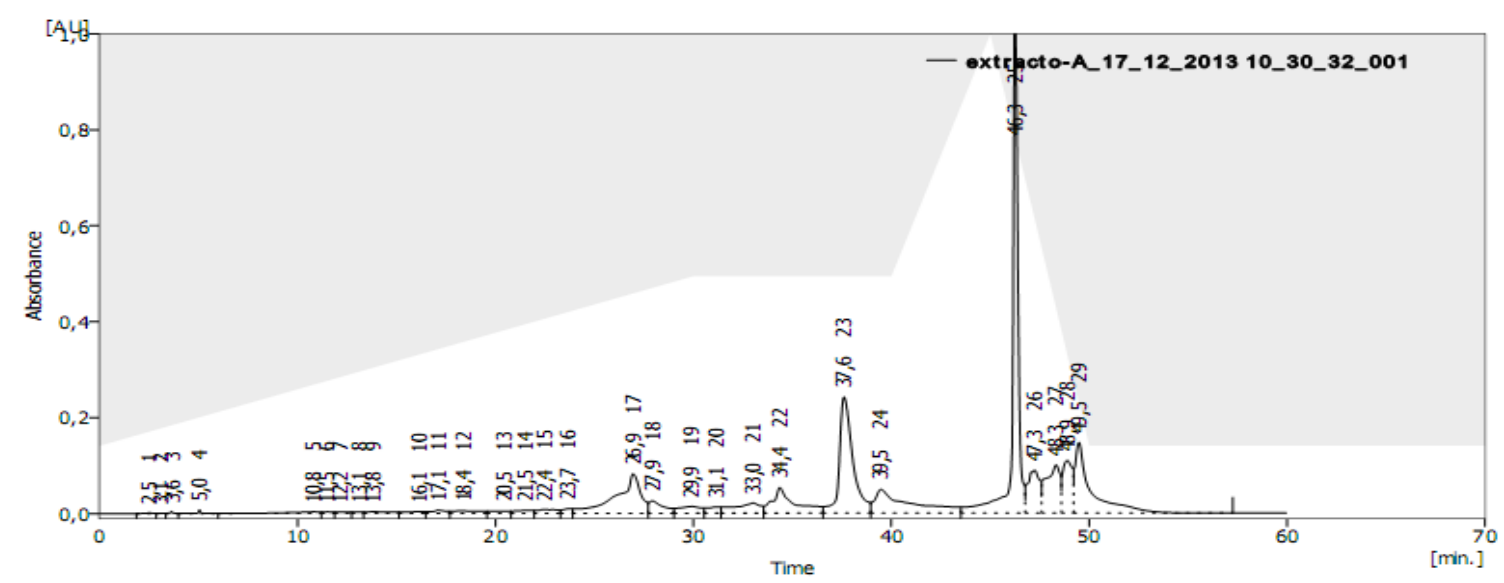


Fig.4 Chromatogram of the chemical constituents of solid residue from the petals of the flowers of T. elatum

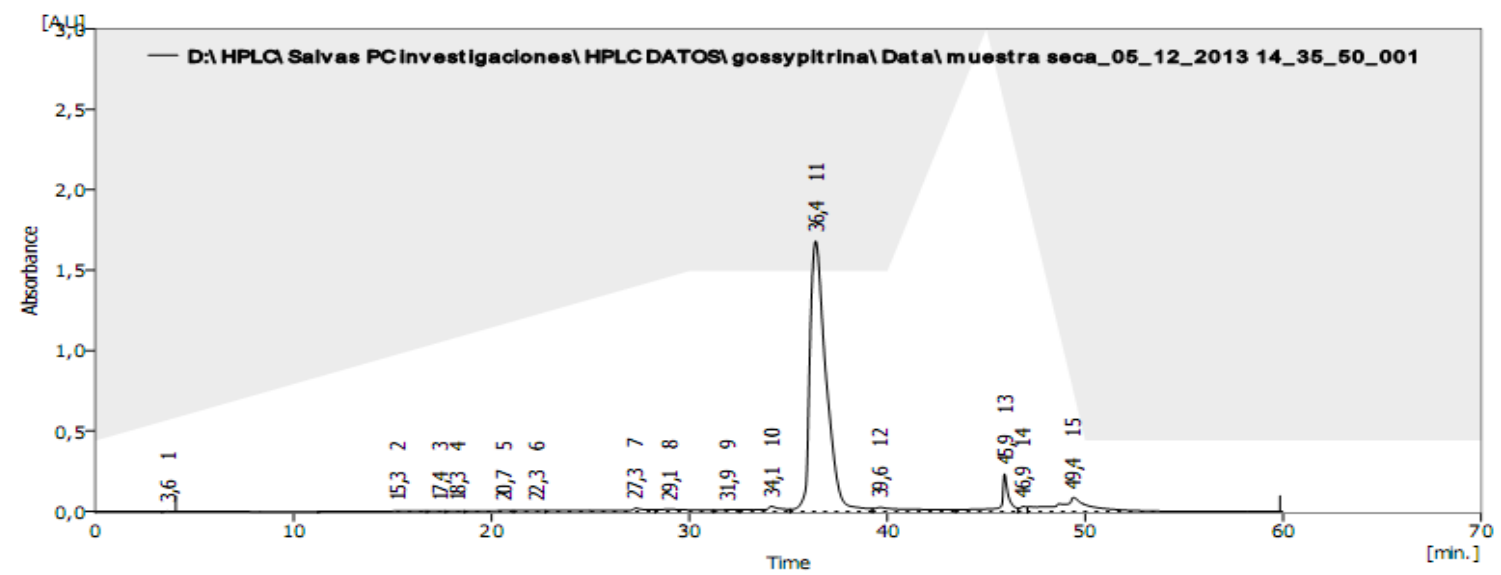

Fig.5 Chromatographic profile of the solid sample after purification by HPLC semipreparative column from the petals of T.elatum

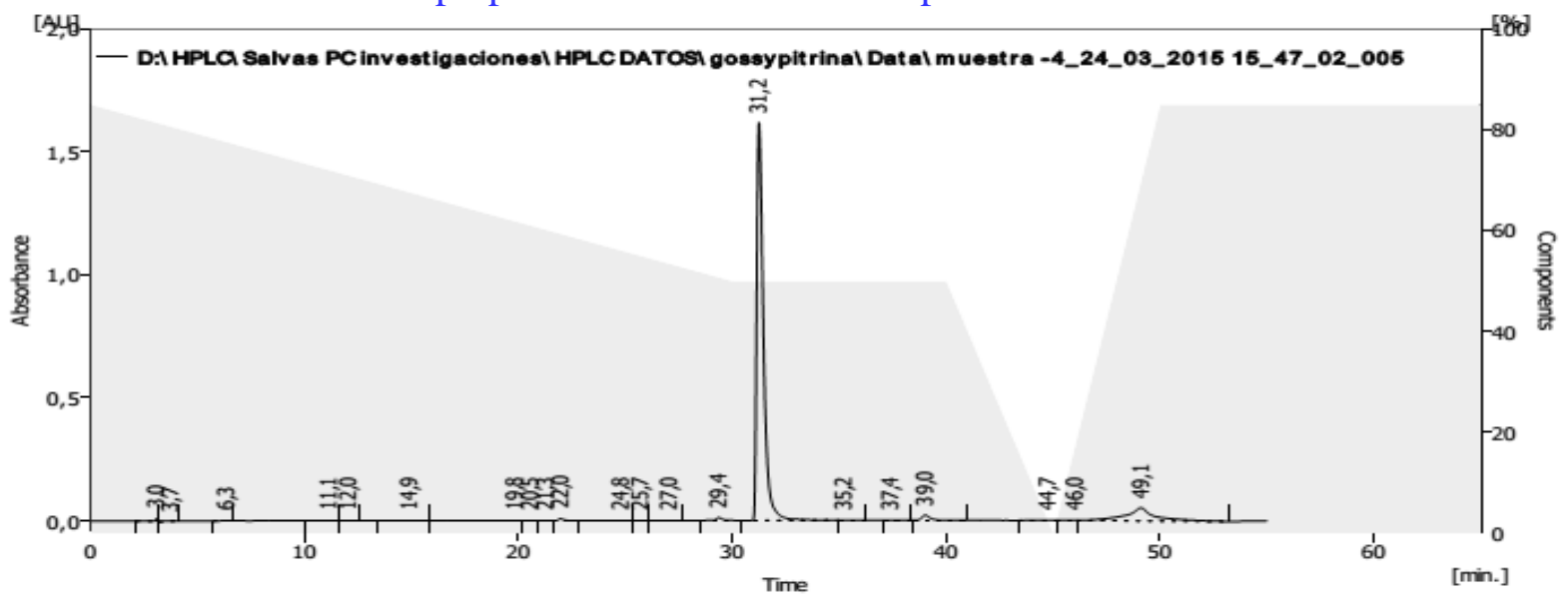

\section{Conclusions}

The present study provides the most thorough qualitative investigation of flavonoids and its derivatives in $T$. elatum performed so far. HPLC, UV and TLC served for dereplication of several major flavonoids. This research showed that, T.elatum can be identified by characterizes profiles of flowers, specific chemical composition can be regarded as distinctive identification character. In identification of ultraviolet spectrum, there are three obvious absorption peaks. There are obvious spots on thin-layer chromatography. It provides reference basis for formulating quality standard of $T$. elatum, authenticity of medicinal flowers and resource utilization.
The method enables the appropriate determination of such phenolics, which obviously contribute to the activity, for the quality control of the drug and of herbal medicinal products containing $T$. elatum.

\section{Acknowledgements}

The authors acknowledge CIDEM (Cuba) for experimental support for this work.

\section{References}

Ablajan, K. 2011. A study of characteristic fragmentation of isoflavonoids by using negative ion ESI-MSn. J. Mass Spectrometry, 46(1): 77-84. 
Acosta de la Luz, L.L., Rodríguez Ferradá, C.A. 2006. Plantas medicinales. Bases para una producción sostenible. Agrinfor, Impresiones MINAG; 124-125.

Cuéllar, A., González, J. 2010. Obtención del glucósido flavonoide gossypitrina de los pétalos de las flores de Talipariti elatum S: W y evaluación de su posible efecto antioxidante. Revista Colombiana de Ciencia Animal; Número 2, Volumen 2, semestre julio-diciembre. ISSN 2027 4297.

González Yaque, J. 2007. Resultados de la extracción de las diferentes partes constitutivas de las flores de Talipariti elatum S.W. (Fryxell). Revista Electrónica Pedagogía Profesional, No. 5. www.pedagogiaprofesional.rimed.cu/

González, J., Cuéllar, A. 2010. Biological activities of Gossypitrin isolated from the flowers of Talipariti elatum S.W. Revista CNIC. Ciencias Biológicas. Número Especial, Volumen 41. ISSN: 0253-568.

Lambert, J.D., Elias, R.J. 2010. The antioxidant and pro-oxidant activities of green tea polyphenols: a role in cancer prevention. Arch. Biochem. Biophysics, 501(1): 6572.

Lu, Y., Yu, K., Qu, H.B., Cheng, Y.Y. 2007. Development of an HPLC-UV-ELSD method for quantification of multiple components of a Chinese medicine made from radix Salvia miltiorrhiza and Panax notoginseng. Chromatographia, 65: 1924.

Márquez, I., Cuéllar, A., Martínez J., Alemán A., Lora J., Castro H. 1999. "Estudio fitoquímico de la especie Hibiscus elatus
S.w". Revista Cubana de Farmacia, 33(2): $127-131$.

Pinheiro Pedro, F. and Justino, Gonçalo, C. 2012. Structural Analysis of Flavonoids and Related Compounds - A Review of Spectroscopic Applications, Phytochemicals - A Global Perspective of Their Role in Nutrition and Health, Dr. Venketeshwer Rao (Ed.), ISBN: 978953-51-0296-0

Pinheiro Pedro, F., Justino Gonçalo, C. 2012. Structural Analysis of Flavonoids and Related Compounds -A Review of Spectroscopic Applications, Phytochemicals - A Global Perspective of Their Role in Nutrition and Health. Dr. Venketeshwer Rao (Ed.), ISBN: 978953-51-0296-0

Roig, J.T. 1974. Plantas Medicinales Aromáticas y Venenosas de Cuba. Editorial Científico Técnica, La Habana.

Valls, J., Millán, S., Martí, M.P., Borràs, E. \& Arola, L. 2009. Advanced separation methods of food anthocyanins, isoflavones and flavanols. $J$. Chromatography A, 1216, 43, 71437172.

Vukics, V., Guttman, A. 2010. Structural Characterization of Flavonoid Glycosides by Multi-Stage Mass Spectrometry. Mass Spectrometry Rev., 29(1): 1-16.

Yaque, J.G., Cuéllar, A., Massi, L., Monan, M., Nossin, E. and François-Haugrin, F. (2016) Isolation and Characterization of Flavonols by HPLC-UV-ESI-MS/MS from Talipariti elatum S.w. American Journal of Plant Sciences, 7, 1198-1204. http://dx.doi.org/10.4236/ajps.2016.7811 $\underline{5}$

\section{How to cite this article:}

José González Yaque, Jacqueline A. Romero Díaz, Armando Cuéllar Cuéllar, Max Monan, Enmanuel Nossin and Frantz François-Haugrin. 2016. HPLC Analysis of the Total Extract and Gossypitrin Isolated from the Petals of Talipariti elatum (S.w) Fryxell (Malvaceae). Int.J.Curr.Res.Aca.Rev.4(7): 89-95. doi: http://dx.doi.org/10.20546/ijcrar.2016.407.011 